\title{
Colombian Language Teachers Abroad: An Overview of Their Professional Experience
}

\section{Docentes colombianos de lenguas en el exterior: Una mirada a su experiencia profesional}

\section{Liana Mercedes Torres-Casierra ${ }^{1}$}

\begin{abstract}
This article presents the preliminary results of an enquiry on the work experience of Colombian language teachers who have entered the workforce in foreign countries. The study aims at unveiling aspects of the personal and professional experience of those graduates that might be relevant for pre-service teachers in local degree programs ahead of their potential move abroad in a growing international mobility context. The study includes data from surveys and personal interviews carried out with a group of 26 participants whose narratives of experience invite one to consider the variables that may either facilitate or hinder one's teaching practice in a foreign workplace and the intercultural communication issues that language teachers may need to deal with. A reflection is brought forward on the needs that teacher training programs at university level in Colombia should address to broaden the scope of their graduates' likely move abroad.
\end{abstract}

Keywords: Colombian language teachers, international mobility, intercultural communication, migration, pre-service teachers, teacher education, teacher identity

\section{Resumen}

Este artículo presenta los resultados iniciales de una investigación sobre la experiencia laboral de profesores de idiomas colombianos que han incursionado en el mercado laboral

1 She holds a PhD degree in Spanish and Latin American Studies from the University of Sydney, and a

Master's degree in Applied Linguistics (TESOL) from Macquarie University, Australia. She currently works at Universidad del Valle, Cali, Colombia. Her research interests include migration studies, curriculum development, and language testing. liana.torres@correounivalle.edu.co

ORCID ID: https://orcid.org/0000-0002-3903-2515

Received: April 14th, 2020. Accepted: November 6th, 2020.

This article is licensed under a Creative Commons Attribution-Non-Commercial-No-Derivatives 4.0 International License. License Deed can be consulted at https://creativecommons.org/licenses/by-nc-nd/4.0. 
en el exterior. El estudio busca develar los aspectos de la experiencia personal y profesional de este grupo de licenciados que pueden ser relevantes para futuros egresados de programas locales de pregrado, teniendo en cuenta las altas probabilidades de que busquen salir del país en el creciente contexto de movilidad internacional. El estudio incluye información de encuestas y entrevistas realizadas con 26 participantes cuyas narrativas de experiencia invitan a considerar las variables propias de sus lugares de trabajo que facilitan o dificultan la práctica docente en el exterior, así como las cuestiones de comunicación intercultural que los profesores de idiomas deben enfrentar. Finalmente se propone una reflexión sobre las necesidades que los programas de licenciatura deben abordar para facilitar la experiencia de sus egresados en el exterior.

Palabras clave: comunicación intercultural, docentes en formación, identidad docente, licenciaturas, migración, movilidad internacional, profesores de lengua colombianos

\section{Introduction}

The relaxation of some of the visa requirements for Colombian passport holders in the last decade has certainly seen an increase of Colombians travelling to a variety of countries around the globe. The 2015 visa exemption for Colombians visiting the Schengen countries is the latest example of this, (Semana, 2016; El Espectador, 2019) facilitating international mobility and adding to the historical dynamics of Colombian emigration flows. Scholarly works (Mejía, 2012; Guarnizo \& Díaz, 1999; Guarnizo, 2008; Bedoya et al., 2015; Roa, 2016) show that the main driver of Colombian migration has been economic, especially from the 1970s onwards, followed by the need to escape from violence, and the armed conflict between the 1980s and 1990s. More recently, reasons have widened including to further career building.

The profile of Colombian migrants is varied and includes low-skilled workers and qualified professionals, voluntary and forced migrants. Their outbound move in the last twenty years has been aided by many factors including lower air fares, social networks that pull out family members or friends to a new country, and a range of work and study opportunities available abroad for those holding professional degrees. Language teachers are naturally attracted by the latter and the process of decision-making to leave for a new country can mostly be seen as the obvious course of action in their career progression. Many enroll in postgraduate studies whereas work options can include short summer immersion courses, fixed-term contracts as au pairs and as language teaching fellows. While this proves to be an enriching personal and professional experience, language teachers may encounter challenging work settings and socio-cultural environments that permeate their teaching practice.

HOW Journal 
Therefore, the understanding of the work culture and the intercultural communication at play, in and outside the language classroom, is central to better respond to the jobs available in this growing market.

This paper explores the work experience of 26 language teaching graduates who have lived abroad for at least three months. From their stories a number of issues related to their teaching training are underscored along with instances of intercultural communication misunderstandings, and common variables in the foreign workplace that have permeated their teaching experience. The analysis of the participants' stories here permits an initial reflection on how language teacher education programs in Colombia can better embrace the future and ever-growing international mobility of their licenciados ${ }^{2}$. To achieve this purpose, the following research questions are addressed:

1. What aspects of the training offered by foreign language programs (i.e., licenciatu$\left.r a s^{3}\right)$, could be enhanced bearing in mind the work and life experience of graduate language teachers abroad?

2. To what extent does intercultural communication in the foreign country permeate the teaching practices of Colombian language teachers there?

3. What specific variables in the foreign workplace can be seen to either facilitate or challenge the teaching experience of Colombian language teachers abroad?

\section{Literature Review}

This research study advances a qualitative approach intending to contextualize the most salient features of the group of migrant teachers investigated and serving to describe their job mobility in their new country. The project combines elements of identity theory, narrative enquiry, and Critical Discourse Analysis (CDA) to present a preliminary analysis of the teaching practice of language teachers graduated in Colombia and working abroad.

Ingrid Piller's (2016) work is indicative of the burden carried by foreign workers who, despite their mastering of the local language, have to go through a process of job deskilling broadening the gap of job prospects between traditionally immigrant communities and their receiving counterparts. As Piller explains, the assumptions around one's native language and one's name quite often seem to provide sufficient evidence of one's linguistic proficiency through linguistic stereotyping (2016, p. 66). Therefore, these migrants are faced with the challenge of adapting to the new social milieu and framing themselves into new identities that help them deal with their foreign reality.

Title given to undergraduate teaching degree holders in Colombia.

Undergraduate teaching degree programme with a duration of 10 semesters in Colombian universities. 
The range of studies on learner identities and migrants, however, has not examined to a great extent the foreign or second language teacher identities. Only a few works have focused on professional identities emerging in institutional or other formal education contexts (Barkhuizen \& Wette, 2008; Liu \& Xu, 2011; Motha, 2006) and early career experiences (Hahl \& Mikulec, 2018; Illieva, 2010; Kayi-Aydar, 2015; Urzúa \& Vasquez, 2008). Those studies have looked at identity construction upon an observed subject, the teacher. However, there is not sufficient understanding on how the subject-teacher makes sense of their own teaching practice (Akkerman \& Meijer, 2011; Matto 2009), and therefore, of their own personal identities forming and negotiating. More information is needed in terms of the conflicting positions to which in-service foreign language teachers have had to adapt in order to succeed in their migration move. Those positions come into play in an interaction with a varied number of stakeholders starting with the gatekeepers, students, teaching colleagues, supervisors, parents, and the local migration policy itself.

Works such as Piller's (2016) illustrate the barriers that migrants are faced with and from this one could anticipate like findings amongst foreign language teachers. Notwithstanding, when those barriers are successfully overcome-by getting a job that matches one's professional background and experience, and with one's personal expectations or desiresthe goings-on afterwards remain uncertain.

In a rather ideal setting, linguistic stereotyping, for example, should dwindle after the non-native speaker is able to get into a determined job position. Yet, another set of conflicts or challenges is likely to emerge upon relating to a new working culture and a broad type of social and professional relations in the new job post. How can foreign in-service teachers respond to those complexities? What can student teachers learn from those who have already experienced working abroad holding migrant and non-native speaker identities? These questions relate intrinsically to the identities that language teachers take on to respond to their new work demands. To be sure, those identities may not be the result of a conscious reflection but may become visible through the undertaking of day-to-day activities, teaching practice, and communication.

Since the graduates' lived experience is studied here through the analysis of narratives, and those narratives are discourses socially and professionally produced, the bottom line of analysis lies on Critical Discourse Analysis (CDA). Fairclough (2012) formulates CDA as a methodology developed through focusing upon a 'social wrong', identifying the obstacles to addressing it, considering if the social order needs the 'social wrong,' and identifying possibilities to overcome the obstacles (p. 13). In the case of Colombian language teachers abroad, their ability to go through the gate-keeping process and obtain a job in a foreign country does not ultimately mean that social and interactional conflicts disappear. On the contrary, their new position as second or foreign language teachers may call for new 
challenges and, in many cases, discrimination and isolation which can be labelled here as social wrongs. Participants' narratives of experience provide insights on the strategies they have used to overcome those obstacles. This serves to analyze what needs to be revisited in licenciatura programs regarding teacher training and pedagogical and socio-cultural awareness skills.

Literature on intercultural communication and pragmatics is also central to addressing the research questions proposed especially in view of the cross-cultural setting where this research study takes place. In this area of study, the works by Holliday et al. (2010), Bloomaert and Verschueren (1991), and Mercer (2004) forestall the elements that may impinge the narratives of experience of the participant teachers. The tools of microanalysis of discourse are taken from ethnomethodology and conversation analysis literature with a special focus on Garfinkel (1967), Drew and Heritage (1992), Cicourel (2003), Candlin and Crichton (2011), and Goffman (1969, 1981). From this body of literature, issues of intercultural communication, such as misunderstandings or miscommunication, cultural presuppositions and the like, are cross-checked within the participants' narratives of lived experience.

\section{Methodology}

This study took place between February 2019 and February 2020. Colombians with a degree in languages teaching and who have travelled abroad to work or study for at least three months were invited to participate. The sample is limited to those criteria only and without further restrictions on age, year of graduation, university, year of departure, type of work and study abroad or current migration status. In this way, the study would attract a larger number of graduates who could then be grouped according to the relevant traits.

Potential participants were reached through a social media campaign and by request to twelve Colombian universities which offer any degree related to languages teaching. Twentysix participants gave their consent and filled out the online survey, and from these, eight people accepted an interview in person and through video calls.

The survey questions look for indications on the background and demographic profile of the participants. They also served to identify their main stimuli for leaving the country of origin, their career path and whether they stayed abroad or returned to Colombia. The interview was designed to open up a space where participants could share their experience, anecdotes, and perspectives on living and working in a foreign country. All interviews were transcribed thoroughly for a detailed analysis on the emerging themes. This involved looking at each participant's discourse and reflecting on their professional and migrant condition and 
the intercultural relations portrayed in their narratives. Then, segments appearing to inform of common experiences amongst participants were grouped and further checked to identify the recurrent discursive patterns they used to describe their training in Colombia and their working life in a foreign country. The interviewees are labelled from P1 to P8 to ensure their anonymity.

\section{Data Analysis and Results}

\section{Survey Takers' Profile}

Twenty-six language teachers, graduates of four Colombian universities, took part of the study with most of the participants, 16, from Universidad del Valle, Cali, and seven from Universidad Industrial de Santander, Bucaramanga. The informants' degree titles include teaching of foreign languages (9), modern languages (9), English (4), Spanish (2), and languages (2). Although only two participants hold a degree in Spanish language teaching, this has not impeded other graduates to find work as Spanish language teachers abroad as will be discussed later.

The main countries of arrival that the participants reported were the United States (11), the UK (5), and France (5) with at least five participants having lived in a second and third country. Twenty-one participants reported having found a job abroad; 12 of them were hired for the first time between one and three months upon their arrival, while four of them did well after 12 months of stay. Three travelled through the Visiting International Faculty program (VIF, now Participate); after a training period in situ, they started working at public schools in the US. Regarding those who travelled to France, three worked as Spanish language assistants at public schools with a fixed-term contract the first year then renewable for short periods of time.

Nineteen informants reported teaching experience in a foreign country at primary (2), secondary (2), high school (5), undergraduate (4), postgraduate (2) levels, and continued education (4). Of thirteen of those have taught Spanish as a foreign language, five have taught English as a second or foreign language, and only one has taught French abroad. Some have taught both English and Spanish, and there is also a minor mention of other subjects different from languages. The remaining participants' work experience has been in menial jobs such as babysitting and cleaning.

The level of studies attained by the majority of informants is at the master's level with 18 holding this degree. Two participants were studying a master at the time of the enquiry. Three reported a doctoral degree and the remaining three had completed only their teacher education program in Colombia (undergraduate degree). Amongst the group 
of 21 informants holding a postgraduate degree, 16 obtained it abroad with masters' titles commonly related to teaching, didactics, applied linguistics, communications, and translation studies.

As can be noted, living abroad has provided major study opportunities for these language teachers which at the same time has translated into job mobility. Half of the sample are currently employed by universities either abroad or in Colombia, while eight people work at primary (2) and secondary (6) schools. The remaining five participants are independent workers, translators, or private tutors.

Eleven informants have permanently returned to Colombia and from the 15 remaining abroad, nine hold permanent residency status, two are on student visas, and four have temporary work permits. Amongst the reasons found to stay abroad, these graduates mentioned the lack of good and stable jobs in Colombia, the violence, and the current state of government affairs. Only two of those who live abroad have plans to return to Colombia. Four of those who returned claimed that they did so because their visa expired while the others did so for family or professional reasons. In total, six of the returnees have plans to go back abroad. Table 1 provides an overview of the survey takers' profile.

\section{Interviewees' Profile}

All survey takers were invited for an interview to discuss more deeply their life and work experience abroad; however, only eight accepted within the time frame requested. A summary of the interviewees' migrant trajectories and their job mobility is presented in Table 2 below. Amongst this group, there are five women and three men with lengths of stay varying from 3 to 16 years to the date of the study. Three have permanently returned to Colombia while the remaining five gained citizenship in their host countries: Canada, Australia, and France. Some of these graduates' migrant trajectories have been multidirectional with three participants having lived in two different countries, one of them in three and another in five countries. Reasons for those trajectories are mostly visa related; those who arrived first in the USA, as language assistants in most cases, migrated to a second country where work or visa conditions were more flexible.

The type of work undertaken by the participants upon arrival concentrates mostly in language teaching assistantships; three of the interviewees travelled to the US to work as Spanish or ESL teachers in American schools (i.e., VIF) and another two did likewise through either a university program or the French government bursaries program. Three participants travelled by their own means to study abroad (P1 and P5) or on a spouse visa (P8). 
Table 1. Participants' Profile - Colombian Language Teachers Abroad $(\mathbf{N}=\mathbf{2 6})$

\begin{tabular}{|c|c|c|c|c|c|c|c|}
\hline & & & & & & (N) & $\%$ \\
\hline & & $(\mathrm{N})$ & $\%$ & \multirow{4}{*}{$\begin{array}{l}\text { University of } \\
\text { graduation }\end{array}$} & U. del Valle & 16 & 61,5 \\
\hline \multirow{4}{*}{ Gender } & Female & 17 & 65,4 & & U. Industrial de Santander & 7 & 26,9 \\
\hline & Male & 9 & 34,6 & & U. Santo Tomás & 2 & 7,7 \\
\hline & & & & & U.Santiago de Cali & 1 & 3,8 \\
\hline & & (N) & $\%$ & & & & \\
\hline \multirow{8}{*}{ Age group } & $20-25$ yo & 1 & 3,8 & & & (N) & $\%$ \\
\hline & $26-30$ yo & 7 & 26,9 & \multirow{6}{*}{$\begin{array}{c}\text { Year of } \\
\text { departure }\end{array}$} & 1994-1998 & 2 & 7,7 \\
\hline & $31-35$ yo & 5 & 19,2 & & $2001-2003$ & 5 & 19,2 \\
\hline & $36-40$ yo & 6 & 23,1 & & $2005-2008$ & 4 & 15,4 \\
\hline & $41-45$ yo & 3 & 11,5 & & $2009-2013$ & 4 & 15,4 \\
\hline & $46-50$ yo & 3 & 11,5 & & 2014-2017 & 7 & 26,9 \\
\hline & over 50 yo & 1 & 3,8 & & $2018-2019$ & 4 & 15,4 \\
\hline & & (N) & $\%$ & & & (N) & $\%$ \\
\hline \multirow{6}{*}{$\begin{array}{l}\text { Highest } \\
\text { degree }\end{array}$} & Undergraduate & 3 & 11,5 & \multirow{5}{*}{$\begin{array}{l}\text { Migration } \\
\text { status }\end{array}$} & $\begin{array}{l}\text { Permanent resident } \\
\text { abroad }\end{array}$ & 9 & 34,6 \\
\hline & Masters & 18 & 69,2 & & Working visa & 2 & 7,7 \\
\hline & Ongoing masters & 2 & 7,7 & & Student visa & 2 & 7,7 \\
\hline & $\mathrm{PhD}$ & 3 & 11,5 & & Temporary visa & 2 & 7,7 \\
\hline & & & & & Returnee & 11 & 42,3 \\
\hline & & (N) & $\%$ & & & & \\
\hline \multirow{7}{*}{$\begin{array}{l}\text { Overall } \\
\text { teaching } \\
\text { experience }\end{array}$} & $1-2$ yrs & 2 & 7,7 & & & (N) & $\%$ \\
\hline & $3-5 \mathrm{yrs}$ & 3 & 11,5 & \multirow{2}{*}{$\begin{array}{c}\text { Experience } \\
\text { teaching abroad }\end{array}$} & Yes & 19 & 73,1 \\
\hline & $5-7$ yrs & 5 & 19,2 & & No & 7 & 26,9 \\
\hline & $8-10$ yrs & 6 & 23,1 & & & & \\
\hline & $12-15 \mathrm{yrs}$ & 1 & 3,8 & & & (N) & $\%$ \\
\hline & over 15 yrs & 9 & 34,6 & & Primary & 2 & 7,7 \\
\hline & & (N) & $\%$ & \multirow{4}{*}{$\begin{array}{l}\text { Levels of } \\
\text { instruction } \\
\text { taught abroad }\end{array}$} & Secondary & 2 & 7,7 \\
\hline \multirow{8}{*}{$\begin{array}{c}\text { First country } \\
\text { of arrival }\end{array}$} & United States & 11 & 42,3 & & High school & 5 & 19,2 \\
\hline & United Kingdom & 5 & 19,2 & & University & 6 & 23,1 \\
\hline & France & 5 & 19,2 & & Vocational/continued ed. & 4 & 15,4 \\
\hline & Canada & 1 & 3,8 & & & (N) & $\%$ \\
\hline & Spain & 1 & 3,8 & \multirow{3}{*}{ Subjects taught } & Spanish, SFL & 13 & 76,4 \\
\hline & Argentina & 1 & 3,8 & & English, ESL, EFL & 6 & 35,3 \\
\hline & Sweden & 1 & 3,8 & & French, FFL & 1 & 5,8 \\
\hline & Australia & 1 & 3,8 & & & & \\
\hline
\end{tabular}


Table 2. Interviewees Migrant Trajectories

\begin{tabular}{|c|c|c|c|c|c|}
\hline Participant & $\begin{array}{l}\text { Number of } \\
\text { years abroad } \\
\text { (year of } \\
\text { departure) }\end{array}$ & $\begin{array}{l}\text { Migrant } \\
\text { status }\end{array}$ & $\begin{array}{c}\text { Countries of } \\
\text { stay/migration }\end{array}$ & First job abroad & Current job \\
\hline P1 (Female) & 10 years (1994) & Returnee & $\begin{array}{l}\text { Germany, } \\
\text { Switzerland, } \\
\text { Great Britain, } \\
\text { Spain, } \\
\text { Ecuador }\end{array}$ & $\begin{array}{l}\text { Cleaning } \\
\text { services \& } \\
\text { some private } \\
\text { Spanish tutoring }\end{array}$ & $\begin{array}{l}\text { Independent } \\
\text { Spanish } \\
\text { teacher }\end{array}$ \\
\hline P2 (Male) & 5 years $(2013)$ & Returnee & US, Spain & VIF Program & $\begin{array}{l}\text { University and } \\
\text { high school } \\
\text { EFL teacher }\end{array}$ \\
\hline P3 (Male) & 16 years $(2004)$ & $\begin{array}{l}\text { Canadian } \\
\text { citizen }\end{array}$ & US, Canada & $\begin{array}{l}\text { Spanish } \\
\text { language } \\
\text { assistant }\end{array}$ & $\begin{array}{l}\text { Full-time ESL } \\
\text { professor }\end{array}$ \\
\hline P4 (Female) & 14 years $(2006)$ & $\begin{array}{l}\text { French } \\
\text { citizen }\end{array}$ & France & $\begin{array}{l}\text { Spanish } \\
\text { language } \\
\text { assistant }\end{array}$ & $\begin{array}{l}\text { Freelance, } \\
\text { start-ups } \\
\text { tele-worker }\end{array}$ \\
\hline P5 (Female) & 12 years $(2008)$ & $\begin{array}{l}\text { Australian } \\
\text { citizen }\end{array}$ & Australia & $\begin{array}{l}\text { Cleaning } \\
\text { services }\end{array}$ & $\begin{array}{l}\text { High school } \\
\text { French teacher }\end{array}$ \\
\hline P6 (Female) & $\begin{array}{l}15.5 \text { years } \\
(2004)\end{array}$ & $\begin{array}{l}\text { Canadian } \\
\text { citizen }\end{array}$ & $\begin{array}{l}\text { US, Tunisia, } \\
\text { Canada }\end{array}$ & VIF Program & $\begin{array}{l}\text { High school } \\
\text { Spanish } \\
\text { teacher }\end{array}$ \\
\hline P7 (Male) & 3 years $(2003)$ & Returnee & US & VIF Program & $\begin{array}{l}\text { University and } \\
\text { high school } \\
\text { EFL teacher }\end{array}$ \\
\hline P8 (Female) & 4 years $(2016)$ & $\begin{array}{l}\text { Australian } \\
\text { citizen }\end{array}$ & US, Australia & $\begin{array}{l}\text { Marketing } \\
\text { assistant }\end{array}$ & $\begin{array}{l}\text { Private tutor } \\
\text { and Spanish } \\
\text { teacher }\end{array}$ \\
\hline
\end{tabular}

In the analysis to follow, it is evident that living and working abroad provided informants with an upward job mobility. This is partly due to the postgraduate studies and professional development courses they had pursued. At the time of the study, all informants were engaged in paid work at high school, university, or were working independently. Three of them currently work teaching ESL or EFL; one teaches French, and three are Spanish language teachers or private tutors. Only P6's job is not related to the teaching of languages. 


\section{Language Teachers' Lived Experience Abroad}

\section{What aspects of the training offered by foreign language programs could be enhanced bearing in mind the work and life experience of graduate language teachers abroad?}

Table 3 below summarizes the items mostly mentioned by the group of graduates regarding both the strengths of their teacher education program and the themes that ought to be improved in view of the mobility that future graduates may have. Participant 1 (P1) states that language teaching graduates' main weakness lies in poor cultural knowledge, involving recognition of their own history, and basic geography of their country. From her experience in managing a Spanish training program at a private university in Cali, P1 believes that graduates "don't read enough, they may be creative, but when it comes to talking about other stuff, such as literature, for example, they are quite weak." She illustrates her point further by explaining that foreigners who come to Cali looking for Spanish courses do have a prior knowledge and have certain qualifications that make them seek a deeper understanding of the local culture, history, geography, etc., and recent graduates miss opportunities in SFL precisely for their lack of knowledge in those fields.

Participants 3, 5, and 6 tell of the issues they faced to get their teaching degrees recognized in the US, Australia, and Canada, respectively. P3 and P5 were unable to fully credit their degrees as language teachers as the units for teaching practicum and pedagogy were insufficient compared with the minimum hours required in the US and Australia. P3 had to do a three-month ESL teaching course to fulfill the requirement while P5 completed a two-year master degree in education to gain registration as a secondary school teacher in Australia. P5 claims that the master program had a major component on pedagogy which her undergraduate degree lacked.

P3 complains that explaining what he studied in Colombia has been quite difficult and thinks it may have to do with the specific contents and subject names in the official transcripts:

There are things that could be improved, such as the subject titles, their translation and their description in the transcripts so that people can really understand. I was rejected in a job, they said 'we have checked with a Spanish speaker and we reached the conclusion that you did not study anything related to the teaching of English in those five years'...

P6's experience in Canada was not different as she had to study five different pedagogy subjects to get a teaching license there, despite holding a master degree. She says that no matter the number of masters one person has, everybody who wants to teach in Canada will need to credit five pedagogy units: "Education in Quebec, primary education, and secondary school pedagogy, special needs education, and diversity." She claims that it will be helpful if Colombian graduates could have at least one of these units in their degree. 
Table 3. Graduates Perspectives on their Teacher Education Training

\begin{tabular}{|c|c|}
\hline $\begin{array}{c}\text { Strengths of their teacher education } \\
\text { program }\end{array}$ & $\begin{array}{l}\text { Aspects that need to be improved to facilitate } \\
\text { international mobility }\end{array}$ \\
\hline 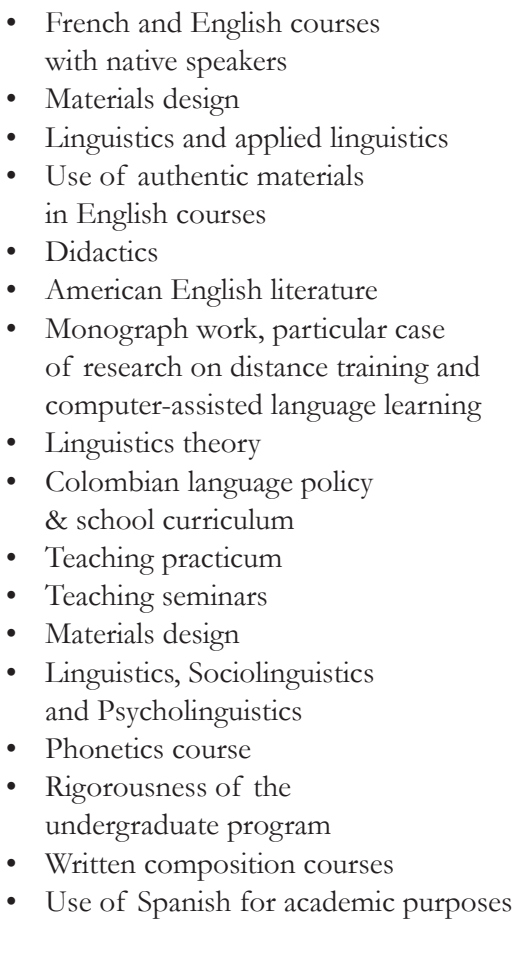 & 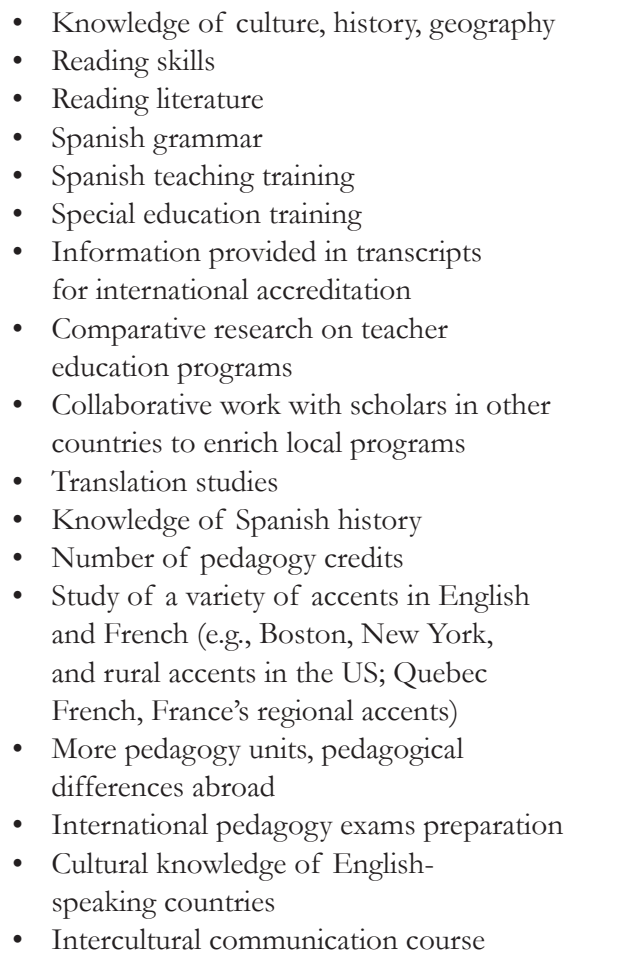 \\
\hline
\end{tabular}

P4's experience goes in tandem with P1's comments on the graduates' lack of familiarity with other areas of knowledge. She illustrates this by describing the exams for teaching registration in France:

They ask too many things about history and their training is based on translation, and we go more towards communication... I sat the test once and the first part was about translating texts, and there was another section where you had to read a piece of Spanish literature of certain century and you had to give answers citing history events, and I don't know about Spanish history, the Spaniards may, but I don't.

P4 could have succeeded in the registration exams if she had had that background on Spanish literature and history, but as she admits, not even Colombians have knowledge of 
their own country's history and this is not addressed in the languages' degree programs. P4 had then a clear idea that she would not be able to teach French or English in France, as she was a non-native speaker of those languages. Interestingly, this contrasts with P5's case in Australia; she has worked as a French language teacher being a non-native speaker and has also been awarded government bursaries to travel to France for professional development short courses in French as a Second language.

P8 is the only one who refers to the training that she received in Spanish language through composition courses. In her work at a marketing agency where she had to edit advertisements from Mexican Spanish to Colombian Spanish, her background in linguistics and knowledge of the Spanish language gave her an advantage to become the editor of other Spanish language varieties. This acknowledgement, however, contrasts with the experiences related by P1 and P2. For P1, graduates from the foreign language teaching program at Universidad del Valle do not have the knowledge of Spanish grammar they need and do not have the skills to teach their own language. Indeed, this licenciatura's purpose is to train students in the teaching of English and French only. Yet, as can be seen from the sample, all seven interviewed graduates from Universidad del Valle have taught Spanish as a foreign language abroad and most of them have stayed in this area of teaching.

\section{To what extent does intercultural communication in the foreign country permeate the teaching practices of Colombian language teachers there?}

The participants provide plenty of examples in which intercultural communication has played a key role in their working lives abroad. In general terms, most of the interviewees refer to this in the adaptation stage to the new country or a new job. For those who travelled through the VIF program, a common observation is made on the initial 'cultural shock' and difficulty to adapt to certain behavior from their students and colleagues. They relate that being sent to rural areas of North Carolina placed them with children from African American communities that were quite rude and did not appreciate their position as foreign teachers. In addition, beyond the normal difficulties of comprehending certain ways of speaking and the distinctive accent of southern rural dwellers, these participants had to deal with very conservative views of their colleagues which they were not in a position to challenge. That is the case of P2 who narrates how, in the staff room at his secondary school, several teachers showed their strong support to the then presidential candidate Donald Trump. P2 was certainly against those views, but he could not voice his stance as he was neither a local nor a permanent teacher.

A rather serious issue of intercultural communication is presented by $\mathrm{P} 6$ in her account of being a victim of sexual harassment: 
The director of the school kept asking me out for dinner, I rejected him and then he started to send memos, he got very intense, he complained about me to the head of the school... they decided to send me to another school, admin staff were very supportive, my colleagues, my director, the head of the ESL department... I didn't know about the process and I didn't know that was actually sexual harassment... I was 24 or 25 and I didn't have experience about that, the gentleman was 10 years older, he was very kind and sweet, but then he started with all of that....

As P6 explains, the matter probably would have been prevented if she had known that her own behavior, which was open, friendly, and affective towards her colleagues, could be misunderstood. She advises new teachers to set clearly, from the beginning, that the certain ways Colombians customarily treat people are a sample of kindness and empathy and do not have anything to do with personal interests.

In other accounts, more positive examples are given related to vocabulary and language misunderstandings that are part of the participants' intercultural communication experience. P8's job in a marketing agency was charged with word use and meanings that would make her Latin American and Spanish colleagues laugh for the sexual connotations implied. The use of words such as coger, pitillo, and chaqueta are just a few she recalls. Yet, in one of the tasks assigned to her team, for creating publicity for a 'motel', P8's boss was shocked to see what she and her team had produced. Based on the Colombian use of the word "motel" the team created an ad with sexual content that greatly differed from the meaning of the word in English. The team had to start their work over although they managed to keep some ambiguous words for the Latin public.

P7 tells how he would always offer to help his female co-workers to carry heavy loads, boxes and packages, and to open the car door for them. They would initially reject his offerings, but later they had the chance to meet casually and he explained why he liked helping them out; he said it was something a gentleman would do and it was common in his country. Afterwards, his colleagues started demanding other male colleagues do what he was doing and it started to create a certain disdain against him from others.

Regarding specific anecdotes on the working culture abroad, some participants mention that working at the school level, as a foreigner, is not an easy task or is not for everyone. P5 had done some previous teaching practicum at the school in which she was later hired as a part-time teacher. She was in charge of one course and had many responsibilities as the group director, not only related to teaching but administrative stuff such as following up students' absences, calling out parents to seek further information, and requesting personal meetings. At that time, understanding parents over the phone was difficult because they spoke quite fast and she was just becoming familiar with the general Australian accent over

Different to its meaning in English, for Colombians, a motel is a place where couples pay for short hourly stays to sustain sexual encounters. 
the phone. She had to ask for help from her colleagues and reconfirm information through emails to avoid mistakes in the due process.

P5 found a friendly work environment in Australia and was able to overcome the initial challenges posed by her new position. A different case is related by P2 who illustrates the differences he felt between his workmates in Colombia and those in the United States in secondary schools:

That school was quite conservative, the teachers didn't share, I was used to share with colleagues at schools in Cali, to have coffee together and talk, but over there everyone was quiet, they didn't talk about personal stuff, there was no room to start getting to know each other. [Sic]

\section{What specific variables in the foreign workplace can be seen to either facilitate or challenge the teaching experiences of Colombian language teachers abroad?}

It is timely to remind one that 25 out of 26 of those surveyed reported to have engaged in teaching roles in foreign countries. That is to say, there is a strong probability that recent graduates who travel abroad can find a teaching job. Typical workplaces are primary and secondary public schools in the US through renowned teaching exchange programs such as Educational Partners International (EPI). Yet, there is a strict selection process that applicants must go through in their countries of origin. Likewise, the French government bursaries for Spanish language assistants require applicants to be rigorously tested in their language skills and other criteria. Participants in this study have also followed other paths to enter the workforce abroad: some travelled to undertake postgraduate studies and their host university allowed them to teach courses or tutorials; others have found professional jobs upon graduating abroad and have pursued permanent residence along the way.

Among the workplace factors that appear to have facilitated these graduates' teaching job experiences are: (1) Foreign schools' needs for degree holders in the teaching of community languages, (2) Availability of fixed-term contracts for new teachers, (3) Availability of support sections (i.e. to assist students' special needs and teachers), (4) Access to professional development programs and continued education, and (5) Friendly and supportive work environments abroad.

134 First, it is certainly acknowledged that due to the constant flows of migration to countries with strong economies, the need for teachers who speak the language of the migrant communities is also steadily growing. Spanish is the first community language in the US with about 37.5 million users. This not only means that Spanish is a language of increasing use in the country, but that school children whose families speak Spanish only need greater support in catching up with English in their mainstream schooling. It can be observed that foreign language graduates have had opportunities to teach both Spanish and English as a second or foreign language in the US, Canada, and Australia, for example. The 
case is somewhat different for those who travelled to France where Spanish native speakers seem to have little opportunities to teach French or English, as the French education system appears to privilege the teaching of community languages by native speakers only.

In that sense, the second factor comes into play as the chances for recent graduates to obtain fixed-term contracts abroad are feasible after a successful application process in the country of origin. One of the main selection criteria is that their date of graduation does not exceed two or three years, depending on the program to which they are applying. Foreign teaching contracts may vary from one to two years if going to the US. Although contract renewals are possible, applicants must comply with the return conditions of their visas, unless they are able to find a visa sponsor.

For the participants interviewed, having a fixed-term contract to start with gave them a huge advantage as they travelled with a stable salary and only had to worry about performing well at their new schools. None of those travelling with VIF or going with a university scholarship to the US engaged in menial jobs as their salary was enough to cover their expenses in the US or they could find extra part-time work within the same school or college.

A third factor facilitating a positive teaching experience abroad amongst the sample was the availability of specific support sections at schools. For some of the interviewees here, learning how to manage cases of students with special needs was a complex task. They had no prior training on detecting this type of needs, as P2, P6, and P7 narrate. Thus, when they encountered groups with children or teens that had learning difficulties or negative behavioral and psychological conditions, such as depression, they were not quite sure how to handle it. Fortunately, these are foreseen issues and schools abroad have dedicated staff who work individually with those students. For the teachers, support goes more on a hierarchical level where school directors, district directors, ESL unit heads, and the like, align to help new teachers with administrative and legal issues.

Another element praised by the participants was the possibility they had to enter professional development and continued education abroad. In some cases, such as P4, P5, P6, and P7, the participants were able to attend courses, seminars, and workshops offered in their workplace as part of their teaching training. In other cases, P2 and P3 for example, it was precisely their first teaching job which allowed them to either save money to undertake postgraduate studies or gain the work experience needed for a successful application for a master's degree scholarship or grant. It is a common reflection amongst this group of participants that only until being abroad did they realize the huge number of opportunities that they had to gain upwards job mobility. For instance, P5's initial plan was to undertake a master's degree in Australia, but once there she learnt about the chances she could have for a permanent job position after completing her practicum credits. This, eventually, meant that she could apply for permanent residency and later citizenship over there. 
Conversely, there are a few variables within the new workplace that hindered the participants' teaching experiences: (1) Demand of greater practicum credits to obtain teaching licenses abroad, (2) Demand of demonstrable training and pedagogy credits in specific levels of education (i.e. primary, secondary, ESL), (3) Local teaching practices unknown to recent arrivals, and (4) Unfamiliar accents and varieties of the local language.

As illustrated in the previous section, one of the common difficulties that the participants living in the US, Canada, and Australia refer to is the lack of evidence to demonstrate that they had undergone sufficient teaching practicum hours and had studied sufficient pedagogy credits in their undergraduate degree programs. Their teaching degrees thus could be easily disregarded by employers. This was the case for P3 in the US who was constantly questioned on his capacity to teach English although being a non-native speaker, and on his ability to teach at secondary and university levels holding a single undergraduate degree. P3's master thesis was a project integrating humor in the ESL classroom. His supervisor's initial comments were: "you are a non-native speaker, how do you dare to say you can teach humor in English, American humor?" In a similar vein, P4, who migrated to France, realized from the very beginning that as a Spanish native speaker, she would only be able to teach Spanish over there: "one cannot pretend to be neither an English teacher, nor a French teacher...we are 'hispanophones'... but we don't have a training to teach Spanish as a foreign language, as they have it here on FLE." [Sic]

Especially for those intending to work permanently in the US, there is a constraint in the unescapable requirement of sitting pedagogy tests to be given full registration there. For those travelling with VIF sponsorship, their contract renewal after the initial two-year period depended on finding a school which would hire them for a third year. However, their local experience for two or three years would not be enough to obtain a longer contract; eventually, they would have to apply for a state-issued teaching license. Only one of the three interviewees related to this issue: P6 completed the whole process and succeeded in obtaining sponsorship and visa renewal in the US. However, she eventually left the US and became a Canadian citizen. The other two, P2 and P7 returned to Colombia.

A third element drawn from the new workplace posing difficulties to informants was the lack of knowledge concerning teaching practices abroad. P2 and P6, for example, share similar experiences about their students not having a notebook to write notes in, but instead, being given handouts at all times. Writing and note-taking in a notebook was not required at their new schools and they both had to learn how to deliver their lessons without this tool which they say is a central part of the teaching practices in Colombia. P6 illustrates the situation in the following extract:

We are used to the notebook, I don't know if they still use it in Colombia, I think so, here children are given handouts, they don't write anything in notebooks, they don't know how to use one, they 
don't have that culture ... 'Wow! What happened here? There's no notebook!' I had to learn, to observe well what the teachers did... but if I had taken a subject on pedagogical differences abroad ... maybe that would have helped me heaps to adapt here more quickly...

Besides the need to adapt to new ways of teaching encountered in the US, P2 had an early experience of a clash with his students and some parents as they disliked his idea of using white paper on both sides. P2 was told that students were able to have as much blank paper as they needed and there was no need to save on it. He had to adjust to this practice and forget about the idea to continue promoting environmentally-friendly practices at his school.

Finally, the participants pointed out to have faced an initial unfamiliarity with the local variety of the language they had studied in Colombia. They all agree that their language skills were quite strong at the time and praise their teachers and university courses for that, but they also agree that their lack of knowledge on the specific varieties of the local language made it a bit troublesome to comprehend people especially in the southern part of North Carolina, US; in Adelaide, Australia; and Montpellier, France. P2, P4, P6, and P7 suggest that undergraduate students should be in contact with those varieties to better adapt to their jobs abroad.

\section{Conclusions}

In broad terms, the participants in this study portray their work and life experience abroad as positive and rewarding. Holding a teaching degree in foreign languages has provided them with a work advantage over fellow migrants in the places where they have travelled. As P8 illustrates, in both the US and Australia, this degree has allowed them to take on jobs where being a Spanish speaker is well regarded, and being a teaching degree holder is seen as a valued proof of their professional skills.

Participants have told of the various pathways they followed for temporary and permanent migration to different countries. Thus, they tell of quite unique experiences while adapting to their new workplace and to the official and administrative requirements in order to pursue their careers further. Eleven out of 26 of those surveyed returned to their home country and have not made plans to go back in the near future. From this, we can claim that the work and life experience of Colombian language teachers abroad is usually profitable and that there are clear possibilities, for those who wish it, to stay there and obtain permanent or at least stable teaching positions. Yet, chances may be limited following local migration policies and requirements. Participants P2, P4, P5, P6, and P8 illustrate how their permanent migration was possible amid the demanding application process they went through.

In view of the research questions, a central issue that graduates may face is the lack of the required number of teaching practicum hours, and pedagogy credits in their degree 
program. This is one of the requirements that poses major delays in their application for a teaching license abroad. Hence, it is essential that Colombian graduates' transcripts thoroughly demonstrate that they have undertaken these subjects as well as state the level of education that they are prepared to teach.

Another important element for students with travel plans to work or study abroad is the undeniable thesis that they will be more likely to teach Spanish courses than any other foreign language. Although this is not always the case and there are experiences of ESL teaching in the sample, graduates are certainly seen as Spanish native speakers with a teaching degree rather than a title in foreign languages teaching. In that sense, university programs should consider the advantages of including more Spanish language teaching related courses. Notwithstanding, further research should reveal whether the recurrent positions that Colombians are able to obtain as Spanish language teachers have more to do with ways of alignment foreign employers seem to uphold systematically.

Only one participant, P8, asserts that her experience of 15 years teaching English in Colombia has opened up opportunities for her to tutor Spanish private lessons abroad, and that her knowledge of academically-bound Spanish posed an advantage to her. However, this claim will have to be further assessed to check if the skills she claims to have are regarded as such in her new role as a Spanish language teacher at a university in Australia. Private tutoring for communicative purposes might differ from delivering full content Spanish courses at school or university levels.

In regard to the question on intercultural communication issues, the interviewees provide some anecdotal examples of words and phrases they misused, but it is not a persistent situation in most of the cases. This is telling about the language proficiency that students are able to reach in their licenciatura. However, specific information on cultural awareness should be included across programs so that graduates are better equipped to recognize behavior and attitudes that can entail ambiguities from their own and their foreign fellows.

As for the third research question, a specific variable challenging the teaching experience of graduates has to do with adapting to unfamiliar accents or varieties of the languages they learnt. Therefore, licenciaturas should offer an extensive approach to regional varieties. This need is also evident from the trends of global migration that privilege movement to rural areas, rather than big cities, where quite different forms of the standard language are spoken.

Finally, the participants coincide in a few recommendations for those willing to travel abroad. They highlight that having clear information on the type of contract they are getting is important, especially in the case of language assistants to the US and Canada. They say that being "open-minded," is also important, as well as being "ready to adapt" to different situations that may be new or that may contrast with their previous teaching experience in Colombia. An example of this is the number of responsibilities that graduates may have as group 
directors to follow up their students' overall performance in all subjects or simply checking on their absences, learning difficulties, and family issues.

\section{References}

Akkerman, S. F., \& Meijer, P. (2011). A dialogical approach to conceptualizing teacher identity. Teaching and Teacher Education, 27, 308-319.

Barkhuizen, G., \& Wette, R. (2008). Narrative frames for investigating the experiences of language teachers. System, 36, 372-387.

Bedoya, M., Garzón, L., \& Roa, M. (2015). Migración laboral de colombianos en la Unión Europea. Programa Editorial Universidad del Valle.

Bloomaert, J., \& Verschueren, J. (1991). The pragmatics of intercultural and international communication. Selected Papers of the International Pragmatics Conference, Antwerp, August 17- 22, 1987 (vol. III), and the Ghent Symposium on Intercultural Communication (vol. I).

Candlin, C., \& Crichton, J. (2011). Discourses of deficit. Palgrave studies in professional and organizational discourse. Palgrave Macmillan.

Cicourel, A. (2003). On contextualizing applied linguistic research in the workplace. Applied Linguistics, 24(3), 360-373.

Drew, P., \& Heritage, J. (1992). Talk at work: Interaction in institutional settings. Cambridge University Press.

El Espectador. (2019, January 9). Los países que no les exigen visas a los colombianos. Retrieved from https://www.elespectador.com/noticias/el-mundo/los-paises-que-no-les-exigen-visalos-colombianos-articulo-833049

Fairclough, N. (2012). Critical discourse analysis. In J. Gee \& M. Handford (Eds.), The Routledge bandbook of discourse analysis (pp. 9-20). Routledge.

Garfinkel, H. (1967). Studies in ethnomethodology. Prentice Hall.

Goffman, E. (1969). On face-work: An analysis of ritual elements in social interaction. In E. Goffman (Ed.), Where the action is: Three essays (pp. 3-36). Allen Lane, The Penguin Press.

Goffman, E. (1981). Forms of talk. Blackwell.

Guarnizo, L., \& Diaz, L. (1999). Transnational migration: A view from Colombia. Ethnic and Racial Studies, 22(2), 397-421.

Guarnizo, L. (2008). Londres latina: La presencia colombiana en la capital británica. México: Universidad Autónoma de México \& Miguel Ángel Porrúa.

Hahl, K., \& Mikulec, E. (2018). Student reflections on teacher identity development in a year-long secondary teacher preparation program. Australian Journal of Teacher Education, 43(12), 42-58.

Holliday, A., Hyde, M., \& Kullman, J. (2010). Intercultural communication: An advanced resource book for students. Routledge. 
Illieva, R. (2010). Non-native English-speaking teachers' negotiations of program discourses in their construction of professional identities within a TESOL program. Canadian Modern Language Review/La Revue canadienne des langues vivantes, 66(3), 343-369.

Kayi-Aydar, H. (2015). Multiple identities, negotiations, and agency across time and space: A narrative inquiry of a foreign language teacher candidate. Critical Inquiry in Language Studies, 12 (2), 137-160.

Liu, Y., \& Xu, Y. (2011). Inclusion or exclusion? A narrative inquiry of a language teacher's identity experience in the 'new work order' of competing pedagogies. Teaching and Teacher Education, 27(3), 589-597.

Matto, A. (2009). Narratives on teaching and teacher education. Palgrave.

Mejía, W. (2012). Colombia y las migraciones internacionales. Evolución reciente y panorama actual a partir de las cifras. Revista Interdisciplinar da Mobilidade Humana, 39, 185-210.

Mercer, N. (2004). Sociocultural discourse analysis: Analysing classroom talk as a social mode of thinking. Journal of Applied Linguistics, 1(2), 137-168.

Motha, S. (2006). Racializing ESOL teacher identities in US K12 public schools. TESOL Quarterly, 40 (3), 495-518.

Piller, I. (2016). Linguistic diversity and social justice: An introduction to applied sociolinguistics. Oxford University Press.

Roa, M. G. (Ed.) (2016). Migración internacional: Patrones y determinantes. Estudios comparados ColombiaAmérica Latina-Proyecto LAMP. Programa Editorial Universidad del Valle.

Semana. (2016, July 5). Colombianos pueden viajar sin visa a siete nuevos lugares. Retrieved from https:// www.semana.com/nacion/articulo/cancilleria-colombianos-pueden-viajar-sin-necesidad-devisa-a-siete-territorios-franceses $/ 472684$

Urzúa, A., \& Vasquez, C. (2008). Reflection and professional identity in teachers' future-oriented discourse. Teaching and Teacher Education, 24, 1935-1946. 